ENTREPRENEURSHIP AND SUSTAINABILITY ISSUES

ISSN 2345-0282 (online) http://jssidoi.org/jesi/

2020 Volume 7 Number 3 (March)

http://doi.org/10.9770/jesi.2020.7.3(71)
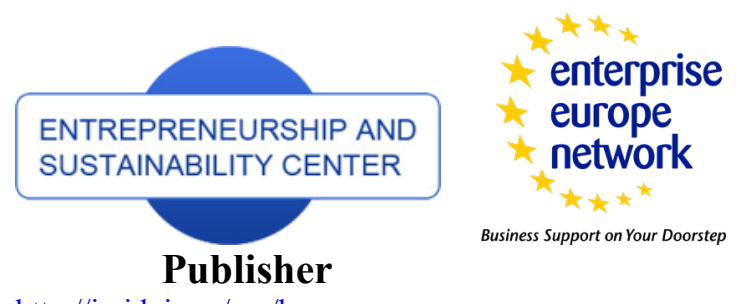

Business Support on Your Doorstep
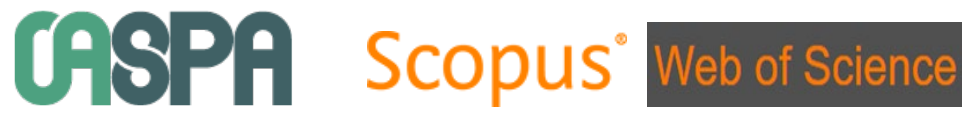

http://jssidoi.org/esc/home

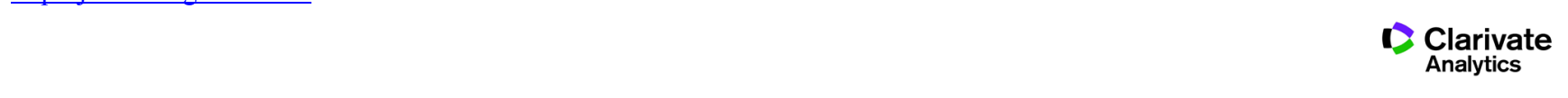

\title{
ASSESSMENT OF BARRIERS TO RENEWABLE ENERGY DEVELOPMENT USING STAKEHOLDERS APPROACH
}

\author{
Arash Khalili Nasr ${ }^{1}$, Maryam Kafizadeh Kashan ${ }^{2}$, Abbas Maleki ${ }^{3}$, Navid Jafari ${ }^{4}$, Hamid Hashemi ${ }^{5}$ \\ ${ }^{1}$ Graduate School of Management and Economics, Sharif University of Technology, Azadi st. P.O.Box 1458889694 Tehran, \\ Iran \\ ${ }^{2,3,4}$ Department of Energy Engineering, Sharif University of Technology, Azadi st. P.O.Box 1458889694 Tehran, Iran \\ ${ }^{5}$ School of Business, London South Bank University 103 Borough Road, London, SE1 0AA, London,United Kingdom \\ E-mail: ${ }^{3}$ maleki@sharif.edu (Corresponding author)
}

Received 16 October 2019; accepted 15 February 2020; published 30 March 2020

\begin{abstract}
Typically, the lack of effective stakeholder participation in a project-especially in the initial planning and implementation stages - has a negative impact on the expected performance of the project. These negative consequences require attempts to encourage their effective participation. Nevertheless, there are some challenges ahead, such as conflict of interest among the stakeholders. For more accurate identification of the interests, objectives, and performance of the stakeholders, this paper proposes an accurate and organized model for the analysis of results from the stakeholder impact index. We implemented the proposed model to determine the existing barriers to renewable energy development in Iran, specifically the wind and solar energy sectors. For data collection, we used the opinions of the experts and other people involved in these industries. Data analysis showed that the current implantation conditions of the solar and wind energy sectors were similar from the stakeholders' perspectives as not bad but poor. The required position of each stakeholder to lift the barriers and develop these industries was identified and their current positions from the desirable conditions were assessed. Finally, some recommendations were presented to improve the stakeholders' conditions and eliminate the barriers.
\end{abstract}

Keywords: renewable energy; stakeholder; wind, sun; development; barriers

Reference to this paper should be made as follows: Nasr, A.K., Kafizadeh Kashan, M., Maleki, A., Jafari, N., Hashemi, H. 2020. Assessment of Barriers to Renewable Energy Development Using Stakeholders Approach, Entrepreneurship and Sustainability Issues 7(3), 2526-2541. http://doi.org/10.9770/jesi.2020.7.3(71)

\section{Introduction}

In executing projects, an important problem is the presence of different stakeholders having diverse interests during the project makespan (Abidin, 2010). Concerning multiple stakeholders can lower risks and in return 
ENTREPRENEURSHIP AND SUSTAINABILITY ISSUES

ISSN 2345-0282 (online) http://jssidoi.org/jesi/

2020 Volume 7 Number 3 (March)

http://doi.org/10.9770/jesi.2020.7.3(71)

improve short term and long term performance (Nasr et al., 2019). A large number of positive or negative interests are actually affected in different stages of a project from start to end. The representatives of these interests are known as the project stakeholders. According to a definition by Freeman (1984), a co-developer of the stakeholder theory, a stakeholder is an individual or group that can either affect or be affected by organizational goals. Stakeholders are usually concerned about the conflict of their interests in a project (Lin et al., 2017; Wallbauma et al., 2010). The interests of stakeholders emerge from a wide range of expectations and values in line with project goals (Lin et al., 2018). Since stakeholders define project success differently, they consider a project successful when they achieve their goals by partaking in that project (Davis, 2014, 2016). The participation of stakeholders must be considered the major factor in "sustainable development" plans (Liu et al, 2013; Yang et al., 2016). Therefore, the project management team should have a clear insight and accurate information regarding the participatory goals of stakeholders in projects in an effort to satisfy stakeholders in addition to sustainable progress in projects (Hwang \& Tan, 2012; Pietrosemoli \& Monroy, 2013). Managers should codify a clear road map to the participation of stakeholders in order to achieve the predetermined project goals and satisfy a wide range of stakeholders (Healey, 1996). The identification of stakeholders is regarded widely as the first step in the analysis of stakeholders (McElroy \& Mills, 2000; Cleland \& Ireland, 2007; Jepsen \& Eskerod, 2008). Various techniques have been proposed to evaluate the stakeholder influencing level such as the score-based approach (Mitchel et al., 1997), the power/interest matrix (Johnson, Scholes, 1999), and the circle of stakeholders (Bourne, Walker, 2008); Delphi survey (Rezk, Radwan, Salem, Sakr, Tvaronavičienè, 2019). These methods were criticized by Wang et al. (2012) for being too qualitative and abstract. It is necessary to develop a quantitative and concrete method for prioritizing the stakeholder influence (Hongyang et al., 2018). In this regard, Olander (2007) proposed a stakeholder influencing level method consisting of three sections, the first of which is based on a technique proposed by Mitchel et al. (1997) to evaluate the type of stakeholders involved in projects. Stakeholders are divided into different groups based on their characteristics, i.e. power, legitimacy, and urgency. The second section is based on a technique proposed by Bourne and Walker (2005) showing the interest/impact index (VIII). This index indicates the impact and interest levels of stakeholders in a project. This section resembles the power/interest matrix (Johnson \& Scholes, 1999). In fact, the power/interest matrix helps interpret how different stakeholders affect the project implementation (Winch \& Bonkeh, 2002; Newcombe, 2003; Olander \& Landin, 2005). The final section of stakeholder influence index pertains to the evaluation of every stakeholder's orientation towards a project: Are they supporters or criticizers? For this purpose, Olander (2007) used the approach proposed by Mills and McElroy (2000) suggesting five different levels of stakeholder orientation towards a project: active disagreement, passive disagreement, neutrality, inactive agreement, and active agreement. Every stakeholder's orientation towards a project determines the direction that stakeholder's influence on the project decision-making process. Olander (2007) used this method to analyze the stakeholder impact on the advances of construction projects. Moreover, Olander and Anne Landin (2007) used the same method to analyze the stakeholder impact on the railway construction project in Sweden. Other researchers benefited from this method differently. For instance, Hongyang Li et al. (2018) deleted the stakeholder orientation factor and used the Factor of Stakeholder Influencing Level (FoSIL) to analyze the stakeholder influence in the development of green buildings. Furthermore, Nhat Hong Nguyen et al. (2009) developed a stakeholder impact index method by considering proximity and stakeholder knowledge in addition to power, urgency, and legitimacy. Then they used this method to analyze the stakeholder influence on state-owned civil projects in Vietnam.

It can generally be stated that the stakeholder impact index is a method of analyzing project stakeholders from the perspectives of stakeholders. This method facilitates the process management, benefits from the positive effect of stakeholders, and mitigates any negative effects (Olander, 2007). All of the factors employed to calculate the impact index are very important in evaluating the stakeholder impact on a project; thus, they should accurately be evaluated. Table 1 shows the analysis procedure and factors used in some prominent papers. Accordingly, all of these studies lack a structured and accurate analysis of results. Since the impact index technique is a conceptual method, it needs to be developed further for the accurate analysis of results. For this purpose, a comprehensive 
ENTREPRENEURSHIP AND SUSTAINABILITY ISSUES

ISSN 2345-0282 (online) http://jssidoi.org/jesi/

2020 Volume 7 Number 3 (March)

http://doi.org/10.9770/jesi.2020.7.3(71)

model was proposed in this paper for the accurate and structured analysis of results through the stakeholder impact method.

Table 1. The workflow of sample researches done with the impact index method

\begin{tabular}{|c|c|c|c|c|c|c|}
\hline & 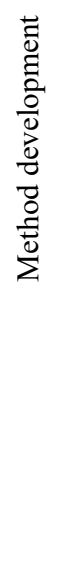 & 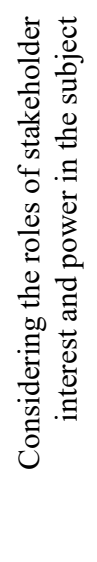 & 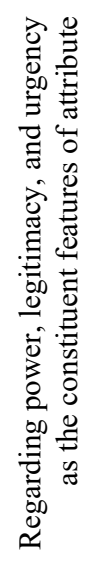 & 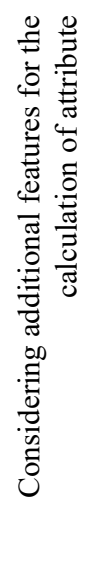 & 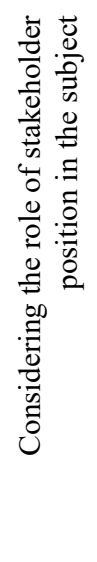 & 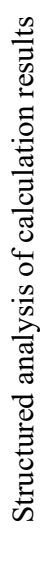 \\
\hline $\begin{array}{l}\text { Toward a Theory of Stakeholder Identification and Salience: Defining the } \\
\text { Principle of who and What Really Counts (Mitchell, R. K., et. al., 1997) }\end{array}$ & $*$ & - & $*$ & - & - & - \\
\hline $\begin{array}{l}\text { Quantifying stakeholder influence in decision/evaluations relating to } \\
\text { sustainable construction in China e A Delphi approach (Li, H., et. al., 2018) }\end{array}$ & - & $*$ & $*$ & - & - & - \\
\hline $\begin{array}{l}\text { Stakeholder Impact Analysis in Construction Project Management } \\
\text { (Olander, S., 2007) }\end{array}$ & $*$ & $*$ & $*$ & - & $*$ & - \\
\hline $\begin{array}{l}\text { A comparative study of factors affecting the external stakeholder } \\
\text { management process (Olander, S., \& Landin, A., 2007) }\end{array}$ & - & $*$ & $*$ & - & $*$ & - \\
\hline $\begin{array}{l}\text { Stakeholder impact analysis of infrastructure project management in } \\
\text { developing countries: a study of perception of project managers in } \\
\text { state-owned engineering firms in Vietnam (Nguyen, N.H., et. al., 2009) }\end{array}$ & $*$ & $*$ & $*$ & $*$ & - & - \\
\hline $\begin{array}{l}\text { Stakeholder impact analysis during post-occupancy evaluation of green } \\
\text { buildings - A Chinese context (Li, H., et. al., 2018) }\end{array}$ & $*$ & $*$ & $*$ & - & - & - \\
\hline
\end{tabular}

Source: Collected by the authors

\subsection{Case Study}

Within the framework of climate changes caused by human activities and market changes, there is an ongoing energy transition across the world. The phenomenon that directs this transition is renewable energy (Mey and Diesendorf, 2018). The use of renewable energies by oil-rich countries like Iran not only contributes to reduced emission of $\mathrm{CO} 2$ but also allows for more oil and gas exports through diversifying energy resources for consumption and strengthening energy security. The recognized potential for renewable energy in Iran has reached $760 \mathrm{MW}$ while its special geographic location has provided high potential for solar energy. In fact, except for the coastline in South Iran, its central and southern areas are very suitable places for the installation of solar cells (Alamdari et al., 2013). According to wind energy atlas, it is estimated that approximately 18,000 MG of wind energy can be harnessed. As a result, to use the proposed model, the selected issue for the study has barriers to the development of solar and wind energy industries in Iran.

Regarding the important role of experts in the development of policies, surveys and interviews were used to collect opinions of the experts and other persons involved in these industries. Data analysis was performed with SPSS. 
ENTREPRENEURSHIP AND SUSTAINABILITY ISSUES

ISSN 2345-0282 (online) http://jssidoi.org/jesi/

2020 Volume 7 Number 3 (March)

http://doi.org/10.9770/jesi.2020.7.3(71)

Section 2 presents the utilized method and research hypotheses. Section 3 presents the mechanism for the identification of stakeholders and data collection and analysis. Finally, summarization and conclusion represented.

\section{Methodology}

There are different methods for the determination of stakeholder management indices. One of these methods is the interest-impact index. This method was developed by Bourne and Walker (2005) to specify the stakeholders' interests in the project and their effectiveness. In this method, the interest index (V) and stakeholder effectiveness index (I) in the given project are scored on a five-point scale (1: very low, 2: low, 3: medium, 4: high, 5: very high) and the interest-impact index is calculated using Equation 1:

$$
V I I I=\left(\frac{V \times I}{25}\right)^{0.5}
$$

This index can determine the weight of each stakeholder with respect to their interest and impact on the project, whereas the interest-impact index cannot show the mechanism of stakeholders' impact and their positions on the project. To address this shortcoming, it was recommended to use two indices, namely the attribute (Mitchell et al., 1997) and the position of stakeholders on the project (McElroy and Mills, 2000).

The stakeholder attribute (A) identifies three stakeholder salience, namely power (P), legitimacy (L), and urgency (U), and specifies how much each stakeholder can influence the project. To use this index, each salience is given a weight between 0 and 1 that the total weight equates to 1 . Based on the experts' opinions from the questionnaire, it was determined that the salience power had the highest weight. As a result, the weight of power was 0.4 and the weights of legitimacy and urgency were 0.3 . The total weight of each attribute index was obtained by calculating the total sum of saliences of each stakeholder.

The underlying reasons to select these three stakeholders were as follows. Power shows that the stakeholder can impose his will on others. Legitimacy shows the compliance of the stakeholder's will with current values and regulations. Urgency means that the given activity or subject can affect the stakeholder, or vice versa, in the shortterm, and this influencing or influenced potential is important to the stakeholder. As a result, each salience can identify the extent of the stakeholder's impact.

According to the Mitchell et al.'s theory (1997), the stakeholders are divided into seven characteristic groups based on three aforementioned attributes: discretionary, dormant, demanding, dependent, dangerous, dominant, and definitive. Latent stakeholders are those with only one attribute.

This is because managers either do not know them at all or do nothing about them. Stakeholders possessing two attributes are regarded as demanding stakeholders. This is because they have urgent claims from authorities. The third group possesses all three attributes and the managers give them a major priority. 


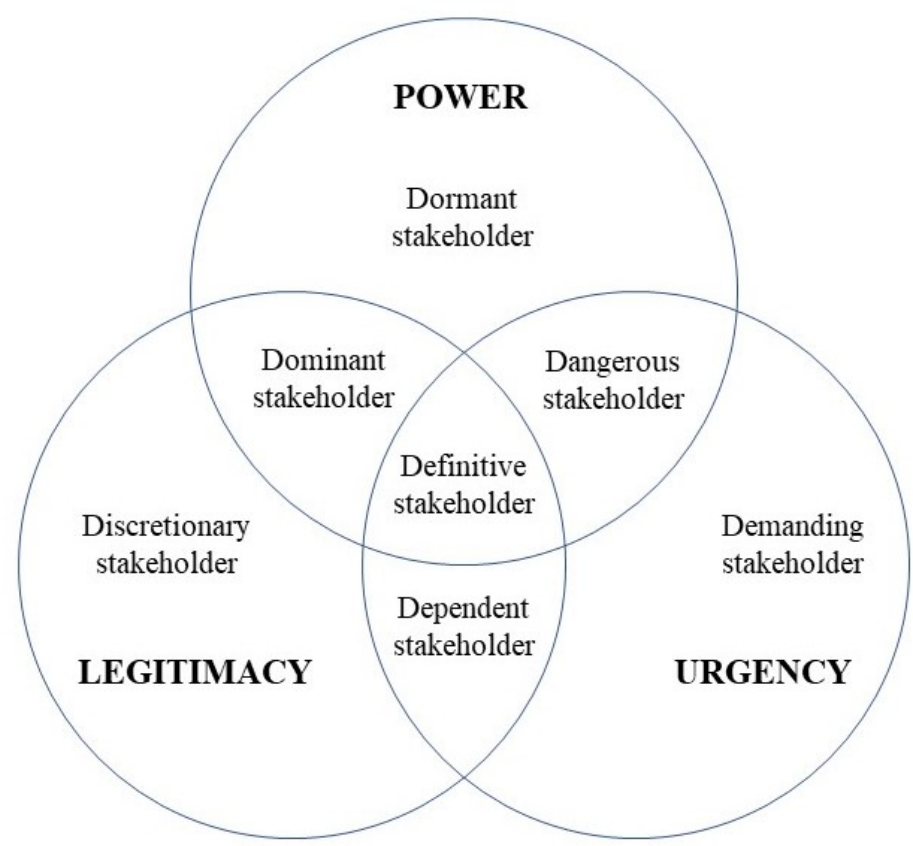

Figure 1. Stakeholder typology based on three salience attributes

Source: Mitchell et al., 1997

Determining the position of stakeholder (POS) establishes whether the stakeholder agrees or disagrees with the project and whether it actively supports its position. Accordingly, POS falls into five categories: Active support $=1$, Passive support $=0.5$, Not committed $=0$, Passive opposition=-0.5, Active opposition=-1. Olander (2007) derived the stakeholder impact index from the combination of these two indices with the interest-impact index. This index is obtained from the numerical multiplication of A, interest-impact index (VIII), and POS (Equation 2).

$$
V I I I \times A \times P O S=S I I
$$

The total position of the project is obtained from calculating the total sum of the impact index of all project stakeholders (Equation 3).

$$
\sum V I I I \times A \times P O S=S I I_{\text {Project }}
$$

The stakeholders with positive and negative SII values have desirable and undesirable impacts on the project, respectively. Moreover, these values should not be reduced during the project's life cycle.

It can be concluded that the interest-impact index can be used to determine how much the stakeholders are interested in affecting a project and to what extent. The impact type index determines how much a stakeholder is influencing and what its impact type is. The POS index shows whether the stakeholders are interested in the project and agree with its implementation. As a result, this index eliminates uncertainties about the interests of stakeholders and their degree of impact on the interest-impact index. 
After calculating these indices, two stakeholder typologies were defined for data analysis: active and passive stakeholders. The active stakeholder is the one with at least two saliences (salience $>0.6$ ) and the interest and impact values in the range of $25 \%$ higher than the measured range (interest and impact $\geq 4$ ). The passive stakeholder is the one with maximum one salience (salience $\leq 0.3$ ) and the interest and impact values in the range of $25 \%$ lower than the measured range (interest and impact $\leq 2$ ).

Assuming that a project is desirable — in terms of feasibility and possibility of spatial development — when active stakeholders agree to it (position $>0$ ) and passive/neutral stakeholders disagree to it (position $<0$ ), first active and passive stakeholder should be identified by determining the position of all stakeholders. Then, ideal conditions should be found, in which the stakeholder with a positive position is active and the stakeholders with the negative and neutral positions are passive. Otherwise, each stakeholder should be directed toward desirable conditions with the application of a suitable strategy. Figure 2 presents these stages in this algorithm.

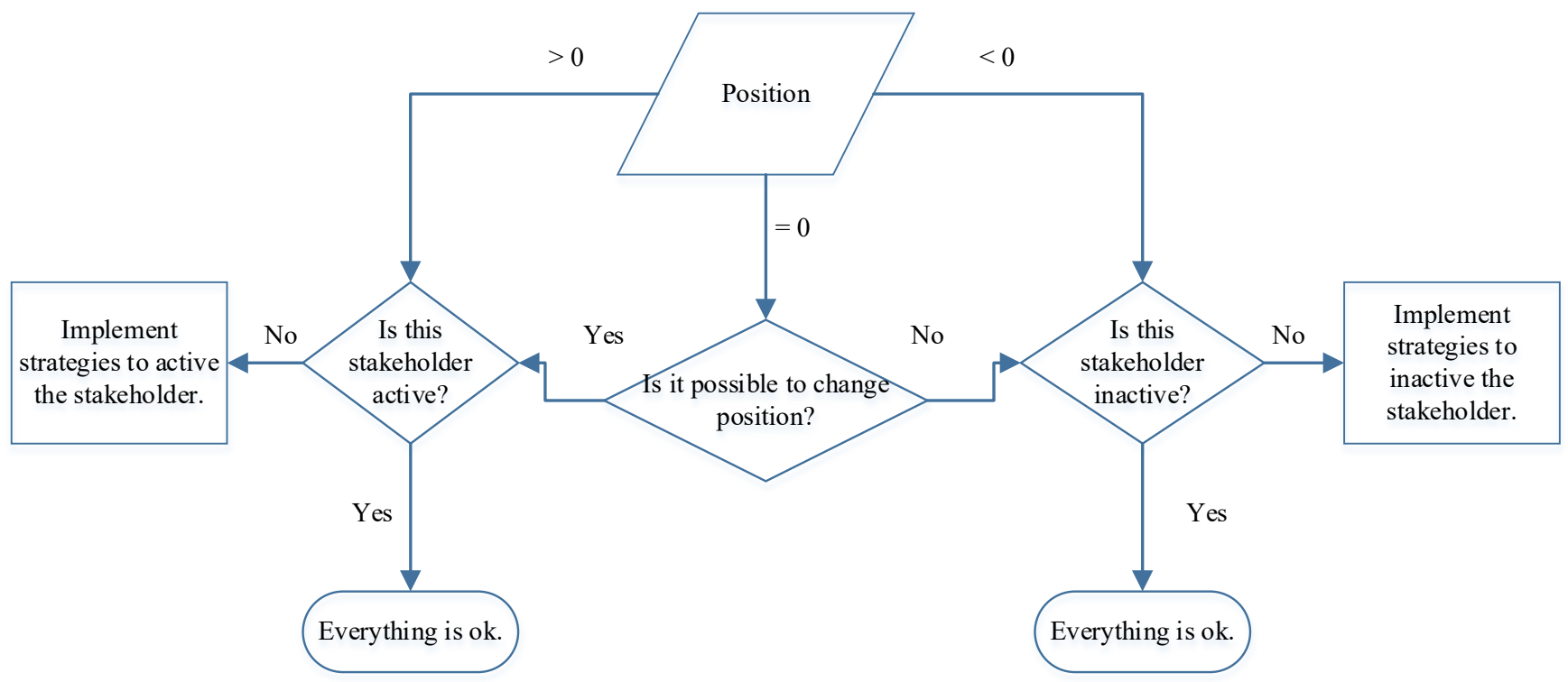

Figure 2. Data Analysis Algorithm

Source: Developed by the authors

\subsection{Hypothesis}

This study hypothesized that failure in achieving developmental objectives, in general, is due to the conflict of interests, objectives, and role of stakeholders. We formed following hypotheses to assess the reason for failure in the successful implementation of developmental plans in the field of renewable energy, specifically the solar and wind energy, in Iran:

H1: Stakeholders that agree with wind energy development are active stakeholders.

$\mathrm{H}$ 2: Stakeholders that agree with solar energy development are active stakeholders.

H3: Stakeholders that disagree with wind energy development or have a neutral position on it are passive stakeholders.

H4: Stakeholders that disagree with solar energy development or have a neutral position on it are passive stakeholders. 


\section{Data Collection and Analysis}

\subsection{Stakeholders}

One prerequisite for identifying stakeholders is to use a systematic procedure. To this end, the stakeholders were divided into internal and external categories. The external stakeholders are effective in the initial stages of the project (Olander and Landin, 2008); whereas, the internal stakeholders have a leading role in the project implementation stage. The internal stakeholders were identified with respect to the value chain of the industry and the external stakeholders were identified by interviewing the experts.

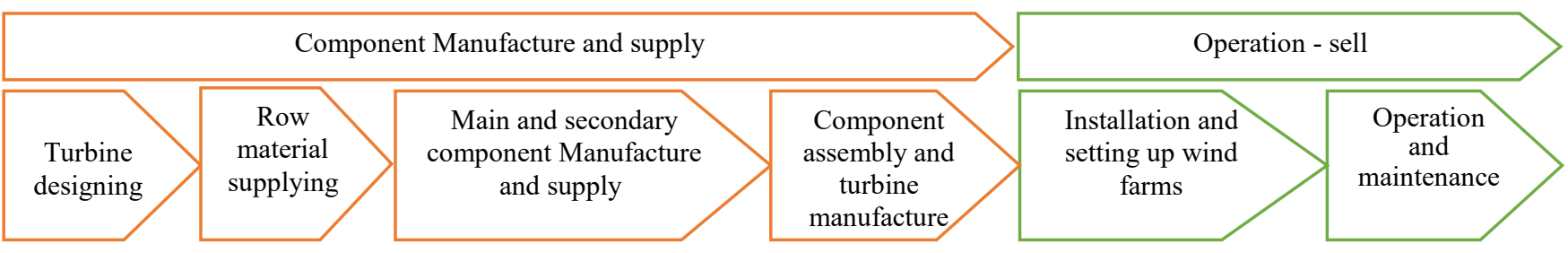

Figure 3. Value chain of wind energy industry

With respect to the value chain of the wind energy industry (Figure 3), the stakeholders in this industry are defined as follows: The turbine designer, raw material supplier, parts manufacturer, turbine assembler, transportation service provider, infrastructure and installation sector, operator, repair and maintenance sector, and investor/owner.

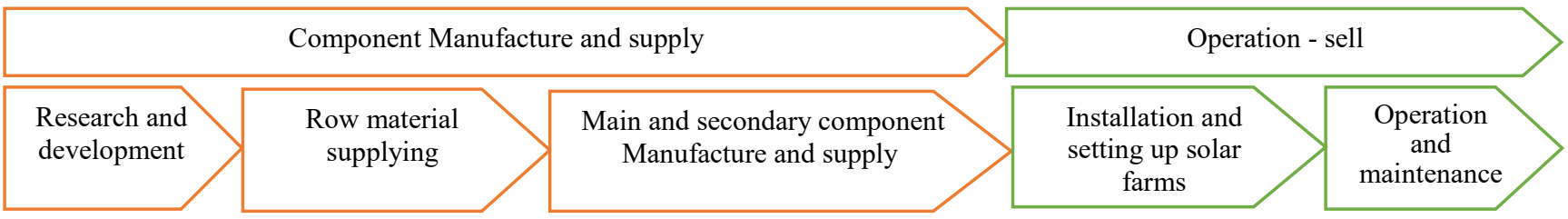

Figure 4. Value chain of solar energy industry

With respect to the value chain of the solar energy industry, the stakeholders in this industry are defined as follows: The panel designer, raw material supplier, parts manufacturer, infrastructure and installation sector, operator, repair and maintenance sector, and investor/owner.

To determine the external stakeholders, the experts were interviewed and the external stakeholders in these two industries were identified as follows: People living near the plants, final consumer, the Ministry of Energy, the Ministry of Petroleum, the Department of Environment, power producers from other renewable energy sources, Non-renewable electricity producers, SATBA (it is Renewable Energy and Energy Efficiency Organization), the Central Bank, domestic banks, the Islamic Consultative Assembly, and the Planning and Budget Organization. 


\subsection{Surveys and Respondents}

To collect the required data, questionnaires were distributed among the experts via social networks and email. Ultimately, 21 questionnaires were completed. In total, 10 respondents held a $\mathrm{PhD}$ degree, eight with a master's degree, and three with a bachelor's degree or studying in an undergraduate program. Moreover, 10 respondents were academicians, nine were active in industrial fields, and two were public sector employees. To design the questionnaire, all internal stakeholders were regarded as one stakeholder, called the energy production group. Due to the multiplicity of the stakeholders, the external stakeholders were reviewed and it was decided to include some stakeholders in the questionnaire. Therefore, the external stakeholders in the questionnaire were local people, SATBA, the Ministry of Energy, Non-renewable electricity producers, the Islamic Consultative Assembly, the Planning and Budget Organization, and banks.

\subsection{Calculation of Impact Index}

According to the data collected following the determination of the interest-impact (Equation 1), the stakeholder impact index was obtained using Equation 2 (Table 2). The final row in this table shows the total sum of this index for each industry.

Table 2. Stakeholder impact index

\begin{tabular}{|l|c|c|}
\hline stakeholders & $\begin{array}{c}\text { Wind energy } \\
\text { industry }\end{array}$ & $\begin{array}{c}\text { Solar energy } \\
\text { industry }\end{array}$ \\
\hline Energy production group & 0.15 & 0.17 \\
\hline SATBA & 0.22 & 0.29 \\
\hline The Ministry of Energy & 0.05 & 0.07 \\
\hline Non-renewable electricity producers & -0.14 & -0.15 \\
\hline Local people & -0.01 & 0.02 \\
\hline The Islamic Consultative Assembly & 0.07 & -0.01 \\
\hline Planning and Budget Organization & -0.07 & -0.10 \\
\hline Banks & 0.03 & 0.01 \\
\hline sum & 0.30 & 0.30 \\
\hline
\end{tabular}

Source: Calculations done by the authors

In the stakeholder impact index, the total stakeholder impact index with negative or zero value indicates the project undesirability, whereas the total stakeholder impact index with a value in the range of $0-1$ indicates the project desirability. This value is more desirable with getting closer to 1. According to the results (Table 2), the total sum of stakeholder impact indices is a positive value $(0.3)$ for both the wind and solar energy industries, indicating the low desirability of both industries in Iran. Although the total sum of the impact index is a positive value, which is desirable, its distance from the ideal threshold value of 1 indicates a considerable distance between the current and ideal conditions. Moreover, a similar condition for the final stakeholder impact index in the wind and solar energy industries suggests that there is no difference between the perceptions of different stakeholders regarding the implementation conditions of these two industries. As a result, similar strategies and policies are required. However, some subtle differences between some stakeholders necessitate small differences in adopted strategies. To investigate the causes of the current conditions and find appropriate improvement strategies, data analysis was conducted according to the algorithm in Figure 2. 


\subsection{Data Analysis}

Figures 5-12 present the median values of collected data for stakeholder position, interest, impact, and salience in solar and wind industries. Numbers 1-8 in the horizontal axis of the diagrams indicate the Energy production group, SATBA, the Ministry of Energy, Non-renewable electricity producers, the local people, the Islamic Consultative Assembly, the Planning and Budget Organization, and the banks.

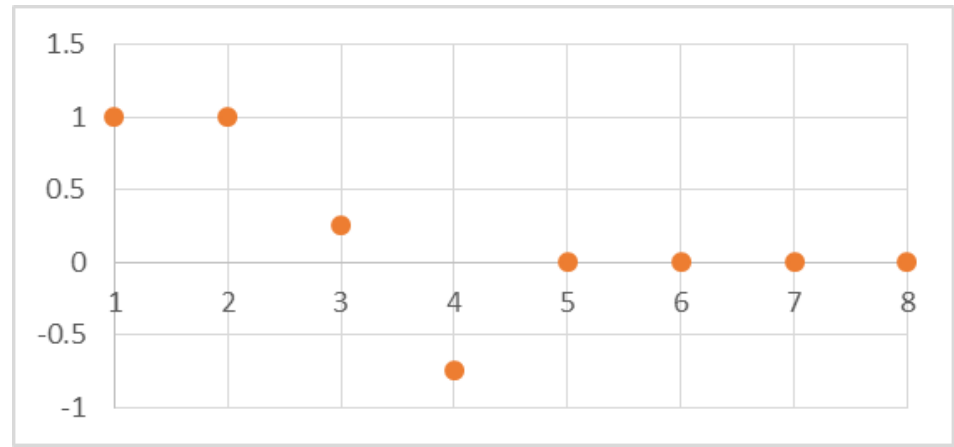

Figure 5. Median Position (solar)

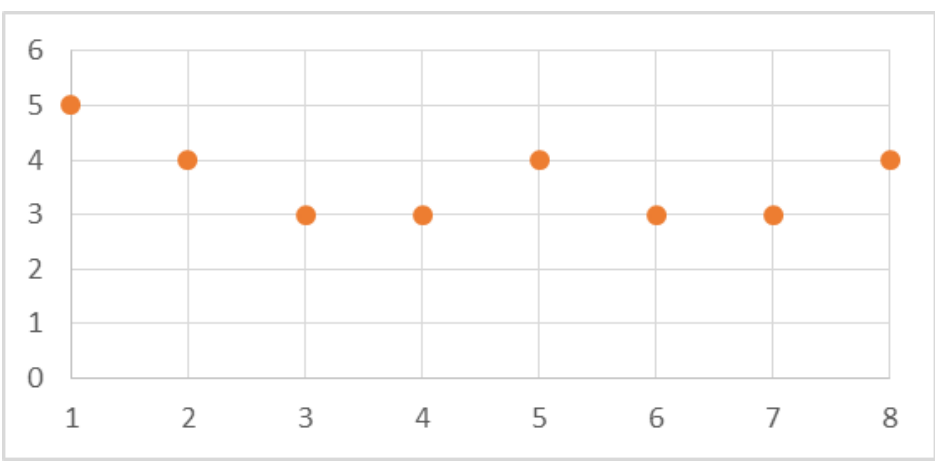

Figure 7. Median Interest (solar)

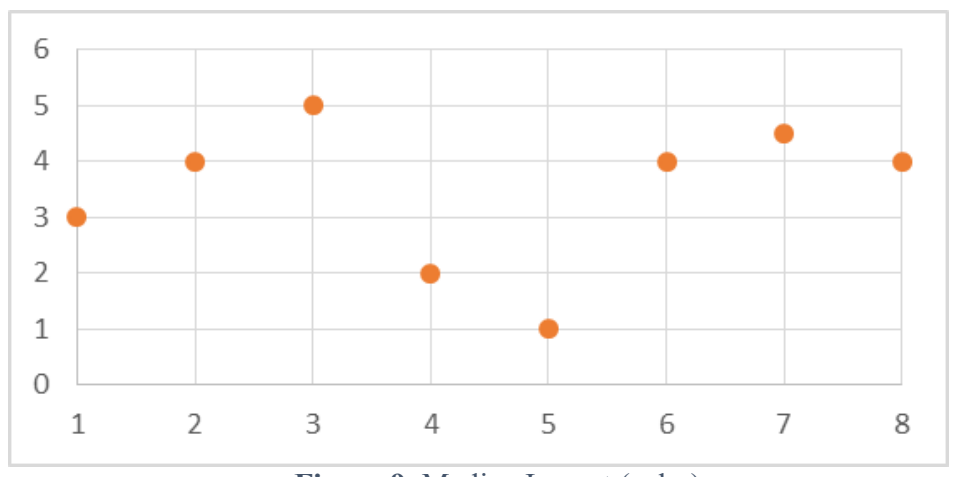

Figure 9. Median Impact (solar)

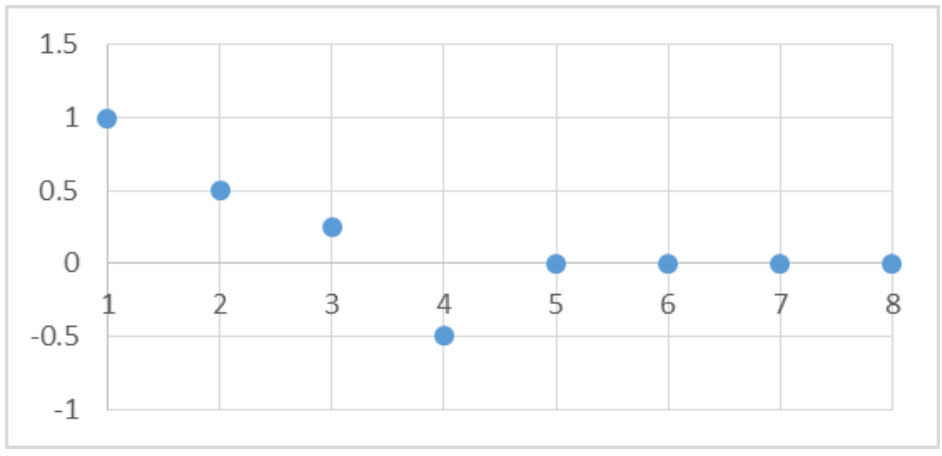

Figure 6. Median Position (wind)

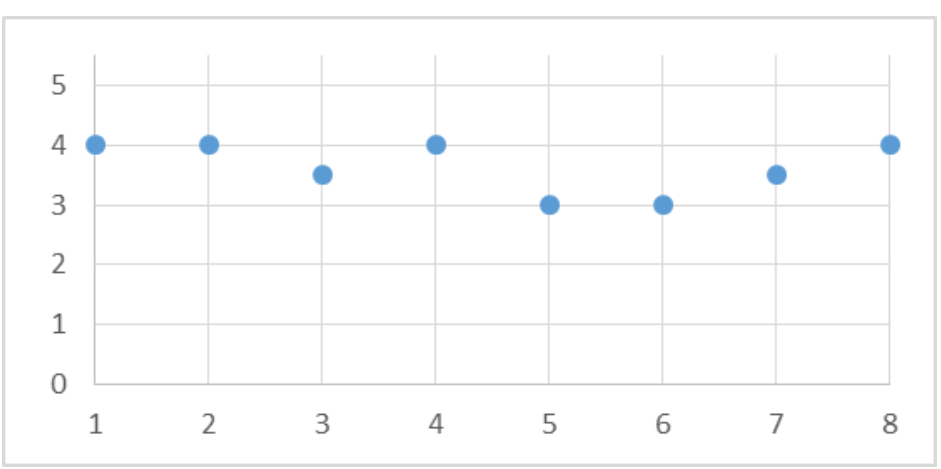

Figure 8. Median Interest (wind)

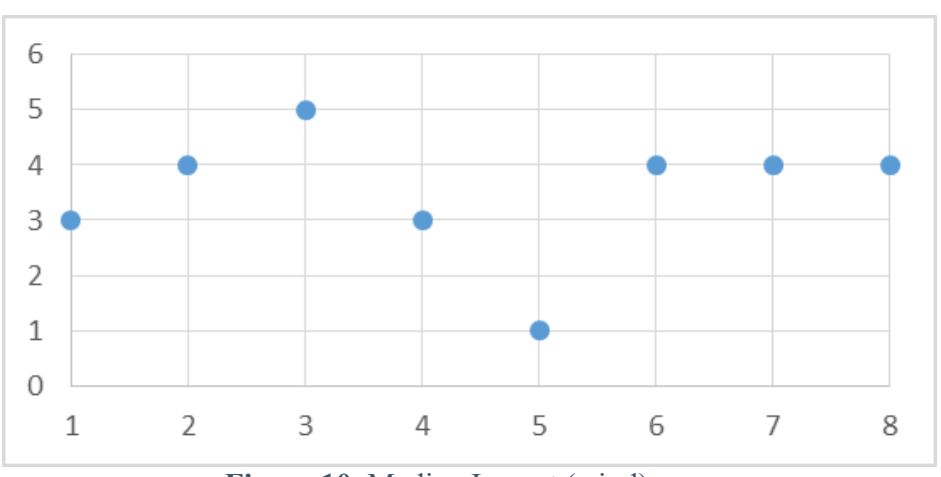

Figure 10. Median Impact (wind) 


\section{ENTREPRENEURSHIP AND SUSTAINABILITY ISSUES}

ISSN 2345-0282 (online) http://jssidoi.org/jesi/

2020 Volume 7 Number 3 (March)

http://doi.org/10.9770/jesi.2020.7.3(71)

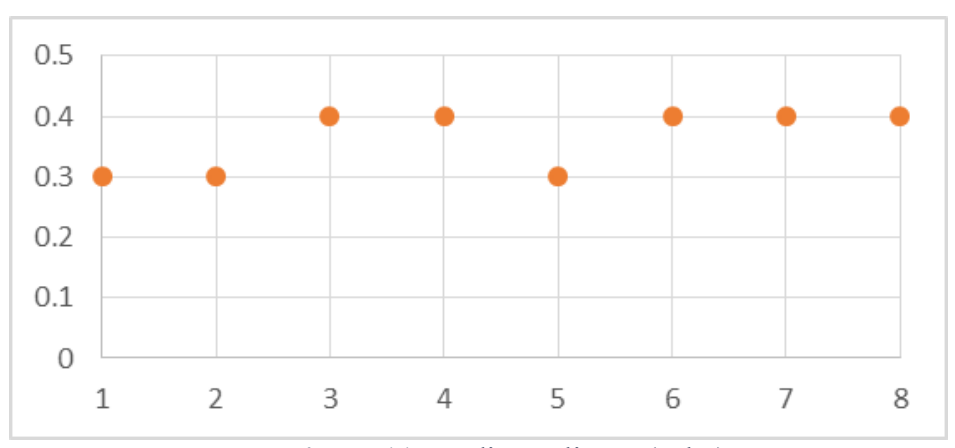

Figure 11. Median Salience (solar)

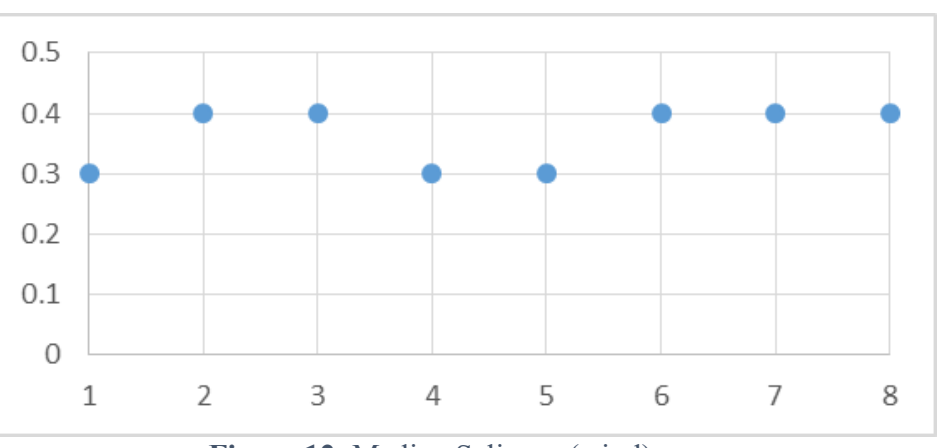

Figure 12. Median Salience (wind)

According to Figures 5 and 6, the Energy production group, SATBA, and the Ministry of Energy have positive position; whereas, the Non-renewable electricity producers have negative position and local people, the Islamic Consultative Assembly, the Planning and Budget Organization, and the banks have a neutral position. Due to the competition, the position of Non-renewable electricity producers cannot be changed. However, the neutral positions of local people, the Islamic Consultative Assembly, the Planning and Budget Organization, and the banks can be altered into a positive position by some changes. For example, the position of the Islamic Consultative Assembly can be improved by providing proper information about the development course in these industries. Moreover, in case of timely payment of power purchase agreements and greater support by SATBA and the Ministry of Energy, the banks' confidence in the commitment of power plants to their obligations enhances which, in turn, improves the bank's position towards developing these industries. Moreover, reducing bureaucratic obstructions in the wind and solar energy industries by the Planning and Budget Organization not only facilitates the development of the power production sector but also changes the indices related to this organization. In addition, reducing bureaucratic obstructions in this organization can indirectly improve the banks' position in these industries. With respect to local people, the only way to change their position in making them informed. To improve the wind and solar energy production conditions, if the neutral position of the stakeholders is turning into positive position, they should be categorized as active stakeholders, along with the Energy production group, SATBA, and the Ministry of Energy; otherwise, they should be categorized as passive stakeholders, along with the Non-renewable electricity producers.

Figures 7 and 8 show that the stakeholders' interest is in a range from moderate (3) to high (4). With respect to the Energy production group, SABTA, and the Ministry of Energy, which have positive positions, the higher level of interest is desirable. It may be even better to develop these industries to achieve ideal conditions to increase their interest. With respect to other stakeholders with a negative and neutral position with no chance of position change, a high level of interest is undesirable. Therefore, appropriate measures should be taken to reduce their interest dependence on the wind and solar energy, so as to reduce their interest in these industries.

According to Figures 9 and 10, the impacts of the stakeholders are different in both the wind and solar energy industries. The Ministry of Energy has the greatest impact, followed by SATBA, the Islamic Consultative Assembly, the Planning and Budget Organization, and the banks. The Non-renewable electricity producers are third in the order of impact with a great distance, followed by the locals with the least impact.

Figures 11 and 12 show the attributes of the stakeholders; that is, each stakeholder is given a value based on its saliences and their weights. For example, if a stakeholder possesses power and legitimacy, its value will be 0.7 , and if it possesses legitimacy and urgency, its value will be 0.6. According to this diagram, the stakeholders of the wind and solar energy possess similarly relevant attributes. Meanwhile, the Energy production group and local people have less number of salience relative to other stakeholders. 
ENTREPRENEURSHIP AND SUSTAINABILITY ISSUES

ISSN 2345-0282 (online) http://jssidoi.org/jesi/

2020 Volume 7 Number 3 (March)

http://doi.org/10.9770/jesi.2020.7.3(71)

The position of all stakeholders on the wind and solar energy industries should be identified based on the algorithm in Figure 2. In addition, we should show which factors in each stakeholder should be changed to improve the conditions. As was mentioned earlier, active stakeholders are those with at least two salience, and interest and impact values of higher than 4 (salience $\geq 0.6$, interest $\&$ impact $\geq 4$ ). The passive stakeholders are those with maximum one salience and interest and impact values of lower than 2 (salience $\leq 0.3$, interest $\&$ impact $\leq 2$ ). To estimate the distance of all factors from assumed desirable values and to establish whether these distances are significant, the Wilcoxon Signed-Ranked Test in SPSS was utilized because of data abnormality. In fact, mean data comparison cannot be used with abnormal data and the medians should be investigated. This test was developed in 1945 to compare the difference in medians.

Tables 3, 4, 5 and 6 present the results. In these tables, $\mathrm{p}<0.05$ shows a significant difference between the desirable factors and assumed desirable values. In addition, $p \geq 0.05$ indicates that the difference is not significant. For a better understanding of differences, the median of all factors is presented in the median observed column.

Table 3. Wind energy stakeholders with positive position

\begin{tabular}{|c|c|c|c|c|c|c|c|}
\hline \multirow{4}{*}{ Position $>0$} & \multicolumn{6}{|c|}{ Wind } & \multirow{4}{*}{$\begin{array}{c}\text { H1 } \\
\text { Hypothesis } 1\end{array}$} \\
\hline & \multirow{2}{*}{\multicolumn{2}{|c|}{$\begin{array}{c}\text { Interest } \\
\text { Hypothesis } \\
\text { interest } \geq 4\end{array}$}} & \multirow{2}{*}{\multicolumn{2}{|c|}{$\begin{array}{c}\text { Impact } \\
\text { Hypothesis } \\
\text { impact } \geq 4\end{array}$}} & \multirow{2}{*}{\multicolumn{2}{|c|}{$\begin{array}{c}\text { Salience } \\
\text { Hypothesis } \\
\text { salience } \geq 0.6\end{array}$}} & \\
\hline & & & & & & & \\
\hline & $\begin{array}{c}\mathrm{P} \\
\text { value }\end{array}$ & $\begin{array}{c}\text { Median } \\
\text { observed }\end{array}$ & $\begin{array}{c}\mathrm{P} \\
\text { value }\end{array}$ & $\begin{array}{c}\text { Median } \\
\text { observed }\end{array}$ & $\begin{array}{c}\mathrm{P} \\
\text { value }\end{array}$ & $\begin{array}{c}\text { Median } \\
\text { observed }\end{array}$ & \\
\hline Energy production group & 0.254 & 4 & 0.001 & 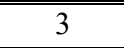 & 0.000 & 0.3 & Not supported \\
\hline SATBA & 0.370 & 4 & 0.500 & 4 & 0.204 & 0.4 & supported \\
\hline The Ministry of Energy & 0.006 & 3.5 & 0.002 & 5 & 0.276 & 0.4 & Not supported \\
\hline
\end{tabular}

Source: Calculations done by the authors

Table 4. Solar energy stakeholders with positive position

\begin{tabular}{|c|c|c|c|c|c|c|c|}
\hline \multirow{4}{*}{ Position $>0$} & \multicolumn{6}{|c|}{ Solar } & \multirow{4}{*}{ Hypothesis 2} \\
\hline & \multirow{2}{*}{\multicolumn{2}{|c|}{$\begin{array}{c}\text { Interest } \\
\text { Hypothesis interest } \\
\geq 4 \\
\end{array}$}} & \multirow{2}{*}{\multicolumn{2}{|c|}{$\begin{array}{c}\text { Impact } \\
\text { Hypothesis } \\
\text { impact } \geq 4\end{array}$}} & \multirow{2}{*}{\multicolumn{2}{|c|}{$\begin{array}{c}\text { Salience } \\
\text { Hypothesis } \\
\text { salience } \geq 0.6\end{array}$}} & \\
\hline & & & & & & & \\
\hline & $\begin{array}{c}\mathrm{P} \\
\text { value }\end{array}$ & $\begin{array}{c}\text { Median } \\
\text { observed }\end{array}$ & $\begin{array}{c}\mathrm{P} \\
\text { value }\end{array}$ & $\begin{array}{c}\text { Median } \\
\text { observed }\end{array}$ & $\begin{array}{c}\mathrm{P} \\
\text { value }\end{array}$ & $\begin{array}{c}\text { Median } \\
\text { observed }\end{array}$ & \\
\hline Energy production group & 0.185 & 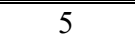 & 0.002 & 3 & 0.000 & 0.3 & Not supported \\
\hline SATBA & 0.435 & 4 & 0.233 & 4 & 0.161 & 0.3 & supported \\
\hline The Ministry of Energy & 0.032 & 3 & 0.002 & 5 & 0.435 & 0.4 & Not supported \\
\hline
\end{tabular}

Table 5. Wind energy stakeholders with negative and neutral position

\begin{tabular}{|c|c|c|c|c|c|c|c|}
\hline \multirow{4}{*}{ Position $\leq 0$} & \multicolumn{6}{|c|}{ Wind } & \multirow{4}{*}{$\begin{array}{c}\text { H3 } \\
\text { Hypothesis } 3\end{array}$} \\
\hline & \multirow{2}{*}{\multicolumn{2}{|c|}{$\begin{array}{c}\text { Interest } \\
\text { Hypothesis } \\
\text { interest } \leq 2\end{array}$}} & \multirow{2}{*}{\multicolumn{2}{|c|}{$\begin{array}{c}\text { Impact } \\
\text { Hypothesis } \\
\text { impact } \leq 2\end{array}$}} & \multirow{2}{*}{\multicolumn{2}{|c|}{$\begin{array}{c}\text { Salience } \\
\text { Hypothesis } \\
\text { salience } \leq 0.3\end{array}$}} & \\
\hline & & & & & & & \\
\hline & $\begin{array}{c}\mathrm{P} \\
\text { value }\end{array}$ & $\begin{array}{c}\text { Median } \\
\text { observed }\end{array}$ & $\begin{array}{c}\mathrm{P} \\
\text { value }\end{array}$ & $\begin{array}{c}\text { Median } \\
\text { observed }\end{array}$ & $\begin{array}{c}\mathrm{P} \\
\text { value }\end{array}$ & $\begin{array}{c}\text { Median } \\
\text { observed }\end{array}$ & \\
\hline Non-renewable electricity producers & 0.000 & 4 & 0.075 & 3 & 0.007 & 0.3 & Not supported \\
\hline Local people & 0.006 & 3 & 0.352 & 1 & 0.158 & 0.3 & Not supported \\
\hline The Islamic Consultative Assembly & 0.001 & 3 & 0.000 & 4 & 0.000 & 0.4 & Not supported \\
\hline Planning and Budget Organization & 0.000 & 3.5 & 0.000 & 4 & 0.000 & 0.4 & Not supported \\
\hline Banks & 0.000 & 4 & 0.000 & 4 & 0.000 & 0.4 & Not supported \\
\hline
\end{tabular}


ENTREPRENEURSHIP AND SUSTAINABILITY ISSUES

ISSN 2345-0282 (online) http://jssidoi.org/jesi/

2020 Volume 7 Number 3 (March)

http://doi.org/10.9770/jesi.2020.7.3(71)

Table 6. Solar energy stakeholders with negative and neutral position

\begin{tabular}{|c|c|c|c|c|c|c|c|}
\hline \multirow{4}{*}{ Position $\leq 0$} & \multicolumn{6}{|c|}{ Solar } & \multirow{4}{*}{$\begin{array}{c}\text { H4 } \\
\text { Hypothesis } 4\end{array}$} \\
\hline & \multirow{2}{*}{\multicolumn{2}{|c|}{$\begin{array}{c}\text { Interest } \\
\text { Hypothesis } \\
\text { interest } \leq 2\end{array}$}} & \multirow{2}{*}{\multicolumn{2}{|c|}{$\begin{array}{c}\text { Impact } \\
\text { Hypothesis } \\
\text { impact } \leq 2\end{array}$}} & \multirow{2}{*}{\multicolumn{2}{|c|}{$\begin{array}{c}\text { Salience } \\
\text { Hypothesis } \\
\text { salience } \leq 0.3\end{array}$}} & \\
\hline & & & & & & & \\
\hline & $\begin{array}{c}\mathrm{P} \\
\text { value } \\
\end{array}$ & $\begin{array}{c}\text { Median } \\
\text { observed }\end{array}$ & $\begin{array}{c}\mathrm{P} \\
\text { value }\end{array}$ & $\begin{array}{c}\text { Median } \\
\text { observed }\end{array}$ & $\begin{array}{c}\mathrm{P} \\
\text { value }\end{array}$ & $\begin{array}{c}\text { Median } \\
\text { observed }\end{array}$ & \\
\hline "Non-renewable electricity producers & 0.000 & 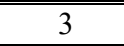 & 0.147 & $\overline{2}$ & 0.004 & 0.4 & Not supported \\
\hline Local people & 0.000 & 4 & 0.137 & 1 & 0.090 & 0.3 & Not supported \\
\hline The Islamic Consultative Assembly & 0.000 & 3 & 0.000 & 4 & 0.001 & 0.4 & Not supported \\
\hline Planning and Budget Organization & 0.000 & 3 & 0.000 & 4.5 & 0.000 & 0.4 & Not supported \\
\hline Banks & 0.000 & 4 & 0.000 & 4 & 0.000 & 0.4 & Not supported \\
\hline
\end{tabular}

The results were similar for the wind and solar energy industries. The Energy production group, SATBA, and the Ministry of Energy should be categorized as active stakeholders because of their positive position. The Energy production group have a desirable interest, and undesirable impact and salience values. Obviously, an ideal condition refers to one at which those stakeholders with a positive position to development have high impact values and those stakeholders with negative and neutral position to development have low impact value. It is worth noting the impact value of the Energy production group with a positive position, as one of the major stakeholders supporting the development, was low and relatively similar to the impact value of Non-renewable electricity producers as the major opposition to the development of these industries. This impact is desirable for Non-renewable electricity producers; however, the lower impact of these stakeholders is desirable for achieving ideal conditions. On the other hand, this low impact value of the Energy production group is not desirable and should be increased. The impact is to some extent affected by the attribute factor that the impact value increases with increasing the attribute of stakeholders. Moreover, the impact of stakeholders reduces with reducing their salience. As a result, one way to increase the impact of the Energy production group is to increase the attribute of these stakeholders. With respect to SATBA, all factors were desirable and it was regarded as an active stakeholder. The Ministry of Energy had desirable impact and salience but required higher interest to be regarded as an active stakeholder.

Tables 5 and 6 show the stakeholders with a negative and neutral position. To achieve maximum condition improvement, these stakeholders should have a positive position first and then the required measures should be taken to activate them. If the position of a stakeholder cannot be changed, that stakeholder should be inactivated. According to Tables 5 and 6, Hypotheses 3 and 4 for all stakeholders were rejected. Non-renewable electricity producers had a low impact value; however, this impact was desirable considering their negative position. On the other hand, their interest and attribute values were high and far from desirable values for a passive stakeholder. Due to the air pollution caused by the generation of electricity from fossil fuels and global warming following $\mathrm{CO}_{2}$ emission, we may reduce the power and legitimacy of these stakeholders by informing people and authorities. The impact and salience of the locals were low and proportional to a passive stakeholder, whereas their interest was higher than a passive stakeholder. Concerning the Islamic Consultative Assembly, the Planning and Budget Organization, and the banks, all three factors - namely impact, interest, and attribute-were higher than that for a passive stakeholder. For these stakeholders, it is more efficient to make their position positive than to reduce other factors. 
ENTREPRENEURSHIP AND SUSTAINABILITY ISSUES

ISSN 2345-0282 (online) http://jssidoi.org/jesi/

2020 Volume 7 Number 3 (March)

http://doi.org/10.9770/jesi.2020.7.3(71)

\section{Conclusions}

\section{Theoretical Contribution}

The main objective of this study was to provide a theoretical method for an organized and accurate analysis of the results obtained from the stakeholder impact index. After accurately determining the stakeholders and identifying the impact, interest, position, and attribute indices, the impact index was first calculated using Equation 2. Negative or zero values for the total impact indices of all stakeholders indicated that the project is undesirable, whereas a total impact index in the range of $0-1$ indicated that the project condition is desirable. This figure becomes more desirable when approaching 1. For an accurate analysis of the causes of these desirable and undesirable conditions, it was recommended to divide the stakeholders into two groups. The stakeholders with positive positions were placed in the first group and the stakeholders with negative and neutral positions-whose positions could not be changed-were placed in the second group. As increasing the total impact index requires the stakeholders with positive positions to have higher interest, impact, and attribute; and stakeholders with negative and neutral positions to have low impact, interest, and attribute; two groups of stakeholders (active vs passive) were defined. According to definitions, active stakeholders were those with the interest and impact values $25 \%$ higher than the measurement range (interest and impact $\geq 4$ ) and at least two salience (salience $\geq 0.6$ ). The passive stakeholders were those with the interest and impact values in a range $25 \%$ lower than the measurement range (interest and impact $\leq 2$ ) and maximum one salience (salience $\leq 0.3$ ). Then, in the ideal conditions assumed for each project, stakeholders in the first and second groups (position $>0$ and position $\leq 0$ ) were defined as the active and passive stakeholders, respectively. After assessing each stakeholder's condition, it was necessary to take the required measures to turn the current conditions into the desirable conditions defined for each stakeholder.

\section{Practical Contribution}

The practical part of the study used the proposed analysis method to investigate the causes of failure in renewable energy development plans, specifically the wind and solar energy sectors. To this end, these industries were analyzed using the value chain of the wind and solar energy industries and the experts and stakeholders' opinions. Finally, eight stakeholders were specified for each industry. All internal stakeholders were regarded as one stakeholder, namely the Energy production group. The other seven stakeholders were local people, SATBA, the Ministry of Energy, Non-renewable electricity producers, the Islamic Consultative Assembly, the Planning and Budget Organization, and the banks. Then, the stakeholder impact index for both industries was calculated and presented in Table 2. This table shows that despite the conditions of these industries in Iran are assessed desirable, it is required to take appropriate improvement measures. It was also found that there was no difference between the development conditions in these two industries from the stakeholders' perspective. Then, the algorithm presented in Figure 2 was used for accurate investigation of the results. The Energy production group, SATBA, and the Ministry of Energy had a positive position, Non-renewable electricity producers had a negative position, and the Islamic Consultative Assembly, the Planning and Budget Organization, and banks had a neutral position. According to research hypotheses, since stakeholders with positive position should be activated and the stakeholders with negative and neutral position should be deactivated, appropriate policies are required to achieve these goals. For example, to activate the Energy production group, such measures as value chain integration that not only increases the influence of this stakeholder but also equips them with more saliences, like power and urgency, can be effective measures. In respect to the Ministry of Energy, it is only needed to increase the interest, which can be done by changing the thoughts governing this ministry. Regarding the Islamic Consultative Assembly, the Planning and Budget Organization, and the banks, it is better to change their position and try to increase the related factors. Considering local people, due to their low impact and attribute similar to passive stakeholders, the best measure in short-term may be to reduce the interest of these stakeholders to turn them into a passive stakeholder; however, the best measure for this stakeholder is to change its position by increasing the number of indices and turning them into an active stakeholder. For example, attempts to eliminate common 


\section{ENTREPRENEURSHIP AND SUSTAINABILITY ISSUES}

ISSN 2345-0282 (online) http://jssidoi.org/jesi/

2020 Volume 7 Number 3 (March)

http://doi.org/10.9770/jesi.2020.7.3(71)

misconceptions about renewable power plants and provide accurate information, such as reduced environmental impacts by means of technological advances, can improve the position of this stakeholder.

To deactivate the Non-renewable electricity producers, the interest and attribute should be reduced. For example, this stakeholder has low legitimacy; therefore, its attribute can be reduced by reducing their considerable power by attracting public attention to the pollutions produced by it.

\section{Limitations of Study}

This study had some limitations, which are recommended to be addressed in future studies. It only assessed the wind and solar energy, whereas the optimal use of energy systems requires the assessment of all renewable and non-renewable energy resources. Based on the identified priorities, appropriate policies were recommended. In addition, due to the low development of the renewable energy sector in Iran, there are still some major disagreements between the experts. Therefore, more expert opinions should be used to reduce the assessment error rate.

This study only considered external stakeholders and assumed all internal stakeholders as an integrated community. Therefore, it is recommended to assess internal stakeholders independently in future studies.

\section{References}

Abidin, N.Z. (2010). Investigating the awareness and application of sustainable construction concept by Malaysian developers. Habitat International, 34(4), 421e426. https://doi.org/10.1016/j.habitatint.2009.11.011

Alamdari, P., Nematollahi ,O., Alemrajabi, A.A. (2013). Solar energy potentials in Iran: A review. Renewable and Sustainable Energy Reviews 21, 778-788. https://doi.org/10.1016/j.rser.2012.12.052

Bourne, L., Walker, D.H.T. (2005). Visualizing and mapping stakeholder influence. Management Decision, 43(5), 649-60. https://doi.org/10.1108/00251740510597680

Bourne, L., Walker, D.H.T. (2008). Project relationship management and the Stakeholder Circle. International Journal of Managing Projects in Business, 1(1), 125-130. https://doi.org/10.1108/17538370810846450

Cleland, D.I. and Ireland, L.R. (2007). Project Management: Strategic Design and Implementation, 5th edn, McGraw- Hill, New York.

Davis, K. (2014). Different stakeholder groups and their perceptions of project success. International Journal of Managing Projects in Business, 32(2), 189e201. https://doi.org/10.1016/j.ijproman.2013.02.006

Davis, K. (2016). A method to measure success dimensions relating to individual stakeholder groups. International Journal of Managing Projects in Business, 34(3), 480e493. https://doi.org/10.1016/j.ijproman.2015.12.009

Freeman, R. E. (1984). Strategic Management: A Stakeholder Approach. Cambridge University Press.

Healey, P. (1996). Consensus-building across difficult divisions: new approaches to collaborative strategy making. Planning Practice \& Research, 11(2), 207e216. https://doi.org/10.1080/02697459650036350

Hwang, B.G., Tan, J.S. (2012). Green building project management: obstacles and solutions for sustainable development. Sustainable Development, 20(5), 335e349. https://doi.org/doi.org/10.1002/sd.492

Jepsen, A.L. and Eskerod, P. (2008). Stakeholder analysis in projects: challenges in using current guidelines in the real world. International Journal of Project Management, 27(4), 335-343. https://doi.org/10.1016/j.ijproman.2008.04.002

Johnson, G., Scholes, K. (1999). Exploring Corporate Strategy, Prentice Hall Europe, London. 


\section{ENTREPRENEURSHIP AND SUSTAINABILITY ISSUES}

ISSN 2345-0282 (online) http://jssidoi.org/jesi/

2020 Volume 7 Number 3 (March)

http://doi.org/10.9770/jesi.2020.7.3(71)

Li, H., Ng, S. T, Skitmore, M. (2018). Stakeholder impact analysis during post-occupancy evaluation of green buildings - A Chinese context. Building and Environment, 128, 89-95. https://doi.org/10.1016/j.buildenv.2017.11.014

Li, H., Zhang, X., Ng, S. T., Skitmore, M. (2018). Quantifying stakeholder influence in decision/evaluations relating to sustainable construction in China e A Delphi approach. Journal of Cleaner Production 173, 160e170. https://doi.org/10.1016/j.jclepro.2017.04.151

Lin, X., Ho, C.M., Shen, G.Q. (2017). Who should take the responsibility? Stakeholders' power over social responsibility issues in construction projects. Journal of Cleaner Production, 154, 318e329. https://doi.org/10.1016/j.jclepro.2017.04.007

Lin, X., Ho, C.M.-F., Shen, G.Q. (2018). For the balance of stakeholders' power and responsibility: a collaborative framework for implementing social responsibility issues in construction projects. Management Decision, 56(3), 550e569. https://doi.org/10.1108/md-05$\underline{2016-0275}$

Liu, J.Y., Low, S.P., Yang, J. (2013). Conceptual framework for assessing the impact of green practices on collaborative work in China's construction industry. Journal of Professional Issues in Engineering Education and Practice, 139(3), $248 \mathrm{e} 255$. https://doi.org/10.1061/(asce)ei.1943-5541.0000153

McElroy, B., Mills, C. (2000). Managing stakeholders in Turner, R.J. and Sinister, S.J. (eds) Gower Handbook of Project Management, 3rd edn, Gower Publishing Limited, Aldershot, 757-775. https://doi.org/10.1108/ws.2000.07949gae.002

Mey, F., Mark, D. (2018). Who owns an energy transition? Strategic action fields and community wind energy in Denmark. Energy Research \& Social Science, 35, 108-117. https://doi.org/10.1016/j.erss.2017.10.044

Mitchell, R. K., Agle, B. R., \& Wood, D. J. (1997). Toward a Theory of Stakeholder Identification and Salience: Defining the Principle of who and What Really Counts. Academy of Management Review, 22(4), 853-886. https://doi.org/10.5465/amr.1997.9711022105

Nasr, A. K., Alaei, S., Bakhshi, F., Rasoulyan, F., Tayaran, H., Farahi, M. (2019). How enterprise risk management (erm) can affect on short-term and long-term firm performance: evidence from the Iranian banking system. Entrepreneurship and Sustainability Issues, 7(2), 1387-1403. https://doi.org/10.9770/jesi.2019.7.2(41)

Newcombe, R. (2003). From client to project stakeholders: a stakeholder mapping approach. Construction Management and Economics, 21(8), 841-8. https://doi.org/10.1080/0144619032000072137

Nguyen, N.H., Skitmore, M., Kwok Wai Wong, J. (2009). Stakeholder impact analysis of infrastructure project management in developing countries: a study of perception of project managers in state-owned engineering firms in Vietnam, Construction Management and Economics, 27(11), 1129-1140, https://doi.org/10.1080/01446190903280468

Olander, S. (2007). Stakeholder Impact Analysis in Construction Project Management. Construction Management and Economics, 25, 277287. https://doi.org/10.1080/01446190600879125

Olander, S. and Landin, A. (2005). Evaluation of stakeholder influence in the implementation of construction projects. International Journal of Project Management, 23(4), 321-328. https://doi.org/10.1016/j.ijproman.2005.02.002

Olander, S., \& Landin, A. (2007). A comparative study of factors affecting the external stakeholder management process. Construction Management and Economics, 26(6), 553-561. https://doi.org/10.1080/01446190701821810

Pietrosemoli, L., Monroy, C.R., (2013). The impact of sustainable construction and knowledge management on sustainability goals: a review of the Venezuelan renewable energy sector. Renewable and Sustainable Energy Reviews, $27,683 \mathrm{e} 691$. https://doi.org/10.1016/j.rser.2013.07.056

Rezk, M.R., Radwan, A., Salem, N.M., Sakr, T.M., Tvaronavičienė, M. (2019). Foresight for sustainable energy policy in Egypt: results from a Delphi survey. Insights into Regional Development, 1(4), 357-369. https://doi.org/10.9770/ird.2019.1.4(6)

Satba-Iranian Renewable Energy Organization (SUNA) Tehran, Iran http://www.satba.gov.ir/en/home

Wallbauma, H., Silvab, L., Plessisc, C., Coled, R., Hoballahe, A., Kranka, S., (2010). Motivating Stakeholders to Deliver Change, 3rd International Holcim Forum for Sustainable Construction-"Reinventing Construction". Universidad Iberoamericana, Mexico City. 


\section{ENTREPRENEURSHIP AND SUSTAINABILITY ISSUES}

ISSN 2345-0282 (online) http://jssidoi.org/jesi/

2020 Volume 7 Number 3 (March)

http://doi.org/10.9770/jesi.2020.7.3(71)

Winch, G. and Bonke, S. (2002). Project stakeholder mapping: analysing the interests of project stakeholders, in Slevin, D.P., Cleland, D.I. and Pinto, J.K. (eds) The Frontiers of Project Management Research, Project Management Institute Inc, Newtown Square, PA.

Yang, R.J., Zou, P.X., Wang, J., (2016). Modelling stakeholder-associated risk networks in green building projects. International Journal of Project Management. 34(1), 66e81. https://doi.org/10.1016/j.ijproman.2015.09.010

\section{Aknowledgements}

The authors sincerely thank all respondents who contributed to achieving better results.

Arash Khalili NASR is Assistant professor of strategic management at Graduate School of Management and Economics, Sharif University of Technology Tehran, Iran

ORCID ID: 0000-0001-6111-5168

Maryam KAFIZADEH KASHAN is a Master graduate of Energy Engineering at Sharif University of Technology, Tehran, Iran.

ORCID ID: 0000-0002-0999-3737

Abbas MALEKI is Associate Professor of Energy Engineering at Sharif University of Technology, Tehran, Iran.

ORCID ID: 0000-0003-2904-4587

Navid JAFARI is a Master graduate at Energy Engineering, Sharif University of Technology, Tehran, Iran.

ORCID ID: 0000-0002-4201-9549

Hamid HASHEMI is an MBA graduate from School of Business, London South Bank University, UK.

ORCID ID: 0000-0001-5587-9903

\footnotetext{
Copyright (C) 2020 by author(s) and VsI Entrepreneurship and Sustainability Center

This work is licensed under the Creative Commons Attribution International License (CC BY).

http://creativecommons.org/licenses/by/4.0/

C. (i) Open Access
} 